\title{
Surface Attachment and Stability of Cross-Linked Poly(ethylenimine)-Epoxy Networks on Gold
}

\author{
Dirk G. Kurth, Gregory K. Broeker, Clifford P. Kubiak, and Thomas Bein* \\ Department of Chemistry, Purdue University, West Lafayette, Indiana 47907
}

Received June 21, 1994. Revised Manuscript Received September 2, $1994^{\otimes}$

\begin{abstract}
The formation of thin films of 3-glycidoxypropyltrimethoxysilane (GPS) on gold was studied by reflection-absorption infrared spectroscopy (RAIR) and optical ellipsometry. Mass changes on the surface were measured with the quartz crystal microbalance (QCM). Thin films of poly(ethylenimine) (PEI) were formed on these modified gold surfaces and crosslinked with the diepoxy compound EPON (bisphenol A/epichlorohydrin epoxy resin). The resulting films are reactive toward $\mathrm{HSiClMe}_{2}$. The expected substitution of chloride at the silicon center is observed, showing that amino and/or oxo ligands are available on the surface. The stability of the PEI/EPON films in water at different $\mathrm{pH}$ and temperatures was studied by electrochemical methods and compared to that of monolayers of octadecylmercaptan (ODM) and octadecyltrichlorosilane (OTS). ODM on gold is quite stable at neutral and basic $\mathrm{pH}$ in aqueous solution up to $100^{\circ} \mathrm{C}$. Films of PEI, covalently bonded to the GPS layer and cross-linked with EPON, are extremely durable. The drastically reduced Faradaic response of these films is consistent with a continuous coating. The films withstand temperatures in the range of $25-100{ }^{\circ} \mathrm{C}$ at $\mathrm{pH} 6$ and 9 for several hours. These films show promise for applications as barrier coatings and thermostable reactive interfaces.
\end{abstract}

\section{Introduction}

Molecular assemblies on solid surfaces have attracted growing attention, both in fundamental studies concerned with reactivity and structure in confined systems and in potential applications ranging from integrated optics and sensors to bioadhesion. ${ }^{1}$ The focus of these studies has been on thiols immobilized on gold surfaces ${ }^{2}$ (self-assembling monolayers, SAMs), on silane coupling agents (SCA) on various hydroxylated surfaces such as silicon, ${ }^{3}$ and on Langmuir-Blodgett films. ${ }^{4}$

One important aspect of these systems is the chemistry of surface-immobilized molecules bearing functional groups such as amines, alcohols, etc., and specifically, the stability of the resulting systems. A number of studies on the reactivity of surface immobilized functional groups have been reported to date, ${ }^{5}$ suggesting that under certain conditions chemical reactions known in solution are transferable to reactions on a

\footnotetext{
* Author for correspondence.
}

- Abstract published in Advance ACS Abstracts, October 1, 1994

(1) For excellent reviews see: Ulman, A. An Introduction to Ultrathin Films, From Langmuir-Blodgett to Self-assembly; Academic Press: Boston, 1991. Bain, C. D.; Whitesides, G. M. Adv. Mater. 1989 28, 506. A special issue on organic thin films is available: Adv. Mater. $1991,3,3-180$.

(2) (a) Nuzzo, R. G.; Korenic, E. M.; Dubois, L. H. J. Chem. Phys. 1990, 93, 767. (b) Bain, C. D.; Troughton, E. B.; Tao, Y. T.; Evall, J.; Whitesides, G. M.; Nuzzo, R. J. Am. Chem. Soc. 1989, 111, 321. (c) Troughton, E. B.; Bain, C. D.; Whitesides, G. M.; Nuzzo, R. G.; Allara, D. L.; Porter, M. D. Langmuir 1988, 4, 365. (d) Strong, L.; Whitesides, G. M. Langmuir 1988, 4, 546 .

(3) (a) Wasserman, S. R.; Tao, Y.-T.; Whitesides, G. M. Langmuir 1989, 5, 1074. (b) Gun, J.; Sagiv, J. J. Colloid Interface Sci. 1986, 112 , 457. (c) Pomerantz, M.; Segmuller, A.; Netzer, L.; Sagiv, J. Thin Solid Films 1985, 132, 153

(4) (a) Gaines, G. L. Insoluble Monolayers at Liquid Gas Interfaces; Interscience: New York, 1966. (b) Roberts, G. Ed. Langmuir.Blodgett Films; Plenum Press: New York, 1990.

(5) (a) Tillman, N.; Ulman, A.; Elman, J. F. Langmuir 1989, 5, 1020. (b) Tillman, N.; Ulman, A.; Penner, T. L. Ibid. 1989, 5, 101. (c) Haller, I. J. Am. Chem. Soc. 1978, 100, 8050 . surface. ${ }^{6}$ We have recently studied the reactivity of thin films of different silane coupling agents in substitution reactions. ${ }^{7}$ We and others ${ }^{8}$ find that the spatial constraints on the surface in some cases prevent common reactions such as quaternization of amines.

In the context of potential applications, the long-term stability of the organic films is a major consideration. Polymerization within Langmuir-Blodgett films, ${ }^{9}$ adsorption of polymers with multiple attachment sites, ${ }^{10}$ or alternating adsorption of polyelectrolytes, ${ }^{11}$ and crosslinking in self-assembled monolayers ${ }^{12}$ are some of the techniques employed to enhance stability. In the present study, we are interested in the formation of stable networks via reaction of polyethylenimine with a surfaceattached epoxide. We examine the formation of thin films of (3-glycidoxypropyl)trimethoxysilane (GPS) on gold with reflection-absorption infrared spectroscopy (RAIR), and optical ellipsometry. Mass changes on the surface were measured with the quartz crystal microbalance (QCM). ${ }^{13}$ The QCM has been used extensively in analytical chemistry, surface science, for thin film deposition control, and electrochemistry. ${ }^{14,15}$

After adsorption of GPS, thin films of poly(ethylenimine) (PEI) were formed on the modified gold surfaces

(6) Kurth, D.; Bein, T. Angew. Chem., Int. Ed. Engl. 1992, 31, 336.

(7) Kurth, D. G.; Bein, T. Langmuir 1993, 9, 2965.

(8) Rieke, P. C., personal communication.

(9) Charych, D. H.; Bednarski, M. D. MRS Bull. 1992, 17 (11), 61.

(10) (a) Sun, F.; Mao, G.; Grainger, D. W.; Castner, D. G. Thin Solid Films 1994, 242, 106. (b) Sun, F.; Castner, D. G.; Grainger, D. W. Langmuir 1993, 9, 3200 .

(11) Lvov, Y.; Decher, G.; Mohwald, H. Langmuir 1993, 9, 481.

(12) Cao, G.; Hong, H.-G.; Mallouk, T. E. Acc. Chem. Res. 1992 25,420 .

(13) (a) Ward, M.; Buttry, D. Science 1990, 249, 1000. (b) Ballantine, D. S.; Wohltjen, H. Anal. Chem. 1989, 61, 704A.

(14) Czanderna, A. W.; Vasofsky, R. Prog. Surf. Sci. 1979, 9, 45.

(15) (a) Thomas, R. C.; Sun, L.; Crooks, R. M.; Ricco, A. J. Langmuir 1991, 7, 620. (b) Sun, L.; Thomas, R. C.; Crooks, R. M.; Ricco, A. J. J. Am. Chem. Soc. 1991, 113, 8550 . 
Scheme 1. Surface Reactions Used for the Construction of the PEI-EPON Network on GPS-Modified Gold (Schematic)

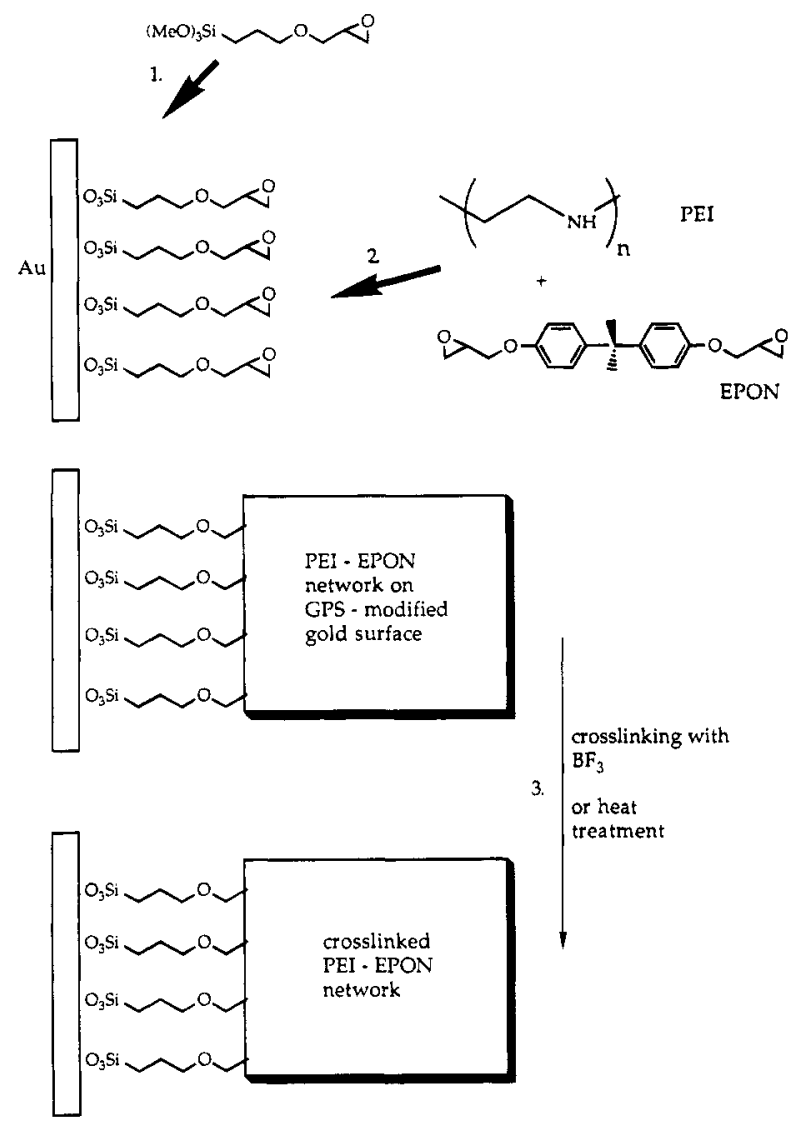

and cross-linked with the diepoxy compound EPON (see Scheme 1). ${ }^{16}$ The stability of these films in water at different $\mathrm{pH}$ and temperatures was studied with electrochemical methods and compared to that of monolayers of octadecylmercaptan (ODM) and octadecyltrichlorosilane (OTS).

We find that films of PEI, covalently bonded to the GPS layer and cross-linked with EPON, are extremely durable, even at $100{ }^{\circ} \mathrm{C}$ and $\mathrm{pH}$ 9. These films show promise for applications as thermostable reactive interfaces.

\section{Experimental Section}

Vibrational Spectra. In a typical determination of the optical response function, a drop of a $40 \mathrm{mM}$ solution of GPS in acetonitrile is placed between two polished $\mathrm{NaBr}$ disks which are immediately mounted in the spectrometer. The absorbance of the solvent at $2254 \mathrm{~cm}^{-1}$ is 0.784 . This information allows us to determine the film thickness. The optical response functions are calculated from the Kramers-Kronig relationship as detailed in ref 17 . Reflection-absorption IR (RAIR) spectra were taken with a Mattson RS-1 instrument combined with a custum-built external evacuated reflection stage using a wire-grid polarizer, f/20 mirror optics, and a narrow-band liquid nitrogen cooled MCT detector.

Materials. GPS was obtained from Aldrich, PEI 6 (mol wt 600) and EPON 828 from Polysciences, Inc. All solvents were

(16) EPON 828 is bisphenol A/epichlorohydrin epoxy resin, CAS RN 25068-38-6, supplied by Polysciences, Inc., Warrington, PA.

(17) Kurth, D. G.: Bein, T. Langmuir, in press. The optical constants of gold as functions of energy were obtained from: Lynch, D. W. Hunter, W. R. In Handbook of Optical Constants of Solids; Palik, E. D. Ed.; Academic Press: Orlando, FL, 1985; p 275. For example, at $1008 \mathrm{~cm}^{-1}, n=12.24, k=54.7$. used as received, unless stated otherwise. For the water contact angle measurements, HPLC-grade water from Aldrich was used. For the adsorption experiments distilled water was used.

Substrates. Evaporated gold-on-silicon wafers were purchased from International Wafer Service; $200 \AA$ of chromium and $2000 \AA$ of gold were vacuum deposited on test-grade 3 in. wafer. The wafers were cut in pieces approximately $15 \mathrm{~mm}$ by $10 \mathrm{~mm}$. Before performing surface reactions, the gold was cleaned in oxygen or nitrogen plasma. Quartz Crystal Microbalances with 9 and $10 \mathrm{MHz}$ resonance frequency were obtained from International Crystal Manufacturing, Oklahoma City, OK. The QCM experiments are described elsewhere. ${ }^{7}$

Adsorption of Organosilanes. For liquid-phase coatings, the precleaned gold substrates were immersed into the solution of GPS in methanol (0.1-20\% by volume). The solution was stirred and immersion times varied from several minutes to several hours. The vapor phase adsorptions were carried out in specially designed glass dishes of $8.5 \mathrm{~cm} \times 3.5 \mathrm{~cm}$. GPS $(200-500 \mu \mathrm{L})$ was dropped at the bottom of the dish with an Eppendorf pipet under nitrogen (static adsorption). The wafer to be modified was immediately deposited onto the dish with the gold side facing the GPS. Adsorptions at elevated temperature were performed in an oven at $60^{\circ} \mathrm{C}$. The adsorption was carried out under dry nitrogen, in a humid environment (placing a drop of water on the blank side of the slide) or under ambient atmospheric conditions (25\% relative humidity). Adsorption times varied from several minutes to several hours. The slides were evacuated ( $10^{-3}$ Torr, molecular sieve pump) and purged with nitrogen to remove an excess layer of physisorbed material. Heating was carried out under nitrogen or vacuum at $80^{\circ} \mathrm{C}$ after the adsorption of the SCA.

Gravimetric Adsorption Measurements. Before the adsorption the QCM crystals were cleaned in a nitrogen or oxygen plasma. The adsorptions were carried out under the same experimental conditions as the adsorption on the gold wafers. The QCM was mounted with a plastic disk in a small glass vial that contained $0.5 \mathrm{~mL}$ of GPS. All measurements were taken under nitrogen atmosphere or vacuum. Flow experiments were carried out in a specially designed flow chamber with several inlets. The QCM, connected by electric feedthroughs, was placed between the inlets and a highvacuum valve. Nitrogen was bubbled through a GPS solution into the chamber (dynamic adsorption).

Hydrolysis Experiments. These in situ RAIR studies were carried out by applying a drop of known concentration to the substrate with a Pasteur pipet. Typically, $200 \mathrm{mg}$ of GPS was dissolved in $30 \mathrm{~mL}$ of methanol; $1 \mathrm{~mL}$ of that solution was diluted in $30-100 \mathrm{~mL}$ of methanol. The wafer was placed in the spectrometer; the chamber was evacuated, and spectra were taken periodically. In between measurements a $100 \mathrm{~W}$ light source, mounted in the chamber $7 \mathrm{~mm}$ above the sample surface, was used to heat the sample to $75^{\circ} \mathrm{C}$. At the end of the period the vacuum was interrupted and liquid water was applied to the substrate to complete the reaction (total heating time $4 \mathrm{~h}$ ).

Surface Attachment of PEI. A typical solution was prepared by dissolving $0.65 \mathrm{~g}$ of PEI and $0.32 \mathrm{~g}$ of EPON in $15 \mathrm{~mL}$ of MeOH; $1 \mathrm{~mL}$ of this solution is dissolved in $100 \mathrm{~mL}$ of $\mathrm{MeOH}$. Different ratios of PEI and EPON are prepared accordingly. The wafer was dip-coated and gently blown dry with nitrogen. The wafer was either heated in air at $80^{\circ} \mathrm{C}$ or exposed to vapors of $\mathrm{BF}_{3}$ in ether for $15 \mathrm{~min}$ (at $25^{\circ} \mathrm{C}$ ) and rinsed with $\mathrm{MeOH}$ (caution: $\mathrm{BF}_{3}$ is a very reactive and poisonous chemical). For this purpose, the wafer is placed in a glass vial and supported on a glass ring $1 \mathrm{~cm}$ from the surface; the vial contains $0.5 \mathrm{~mL}$ of $\mathrm{BF}_{3}$ in ether. QCM experiments are carried out similarly. The wafer coated with PEI and EPON was exposed to $\mathrm{HSiClMe}$ vapors in a similar procedure and subsequently rinsed with $\mathrm{MeOH}$ under nitrogen. 
Electrochemistry. Films of OTS and ODM on gold were prepared according to literature procedures. ${ }^{18}$ The electrochemical experiments were carried out in a solution of $0.5 \mathrm{M}$ $\mathrm{K}_{2} \mathrm{SO}_{4}$ and $1 \mathrm{mM} \mathrm{K}_{2} \mathrm{Fe}(\mathrm{CN})_{6}$ in a conventional three-electrode cell with argon sparging. The $\mathrm{pH}$ of the solution was adjusted with $\mathrm{H}_{2} \mathrm{SO}_{4}$ or $\mathrm{NaOH}$. The electrodes, of $1.5 \mathrm{~mm}$ diameter, were polished and cleaned in an ultrasound bath in water for $10 \mathrm{~min}$ before the electrochemical experiment. Prior to film adsorption the electrodes were cleaned with an acidic hydrogen peroxide (piranha) solution (1:1 concentrated $30 \% \mathrm{H}_{2} \mathrm{O}_{2} / \mathrm{H}_{2-}$ $\mathrm{SO}_{4}$. Caution: piranha solution reacts violently with many organic materials and should be handled with extreme care). The potentials were measured versus SCE; the reference electrode was connected to the cell via a long bridge $(12.5 \mathrm{~cm})$ and was kept at room temperature. The cyclic voltammograms were recorded with a Princeton Instruments Research Model 176 current follower, equipped with an electrometer probe Model 178, a EG\&G Universal Programmer Model 175, and an HP 7045 recorder. The sweep rate was $200 \mathrm{mV} / \mathrm{s}$ and the scan range was from -0.6 to $0.1 \mathrm{~V}$. The electrochemical cell was immersed in a bath; the heating rate was $1-2{ }^{\circ} \mathrm{C} / \mathrm{min}$.

\section{Results and Discussion}

Thin Films of (3-Glycidoxypropyl)trimethoxysilane (GPS). The following discussion begins with simulations of RA-GPS spectra on gold surfaces to elucidate the general trends of chemical and optical effects. ${ }^{17}$ The isotropic optical response function was determined from the following sources: a GPS-acetonitrile mixture, liquid GPS that is monomeric, and polymerized GPS, which was heated in aqueous solution at $90^{\circ} \mathrm{C}$ for $12 \mathrm{~h}$. The optical response function of liquid GPS is shown in Figure 1.

Figure 2 shows the $\mathrm{Si}-\mathrm{O}$ stretching region of GPS transmission spectra of the above sources that served for the determination of the optical response functions. As expected, the changes in the transmission spectra are quite significant. The mode assignments of methoxy silane groups are summarized in Table 1 . The band positions and assignments for GPS transmission spectra are summarized in Table 2. The methoxy silane group shows one broad band centered at $1100 \mathrm{~cm}^{-1}$ (neat) or $1086 \mathrm{~cm}^{-1}$ (in $\mathrm{MeCN}$ ) for the $\mathrm{Si}-\mathrm{O}-\mathrm{C}$ stretch and another characteristic band at $1192 \mathrm{~cm}^{-1}$ for the $\mathrm{CH}_{3}$ rocking mode. Upon hydrolysis we observe two bands with maxima at 1120 and $1020 \mathrm{~cm}^{-1}$ for the $\mathrm{Si}-\mathrm{O}-\mathrm{Si}$ stretching modes of the polysiloxane moiety. The most intense $\mathrm{Si}-\mathrm{O}-\mathrm{Si}$ band appears to shift to higher energy on increased cross-linking. Also, we notice a weak new band at $1733 \mathrm{~cm}^{-1}$ which is attributed to an aldehyde. Epoxides are known to rearrange to aldehydes.

Isotropic RA simulations were calculated with an angle of incidence of $84^{\circ}$ and a film thickness of $15 \AA$, which corresponds to the length of an extended GPS molecule. Figure 3 shows the RA simulations. The bottom spectrum corresponds to the GPS/acetonitrile mixture; only the GPS part is shown. The dispersion of the siloxane modes has a significant influence on the band position and shape in the simulated reflectance spectra. The bands are shifted to higher frequency by 10 to almost $40 \mathrm{~cm}^{-1}$. The band positions of the $\mathrm{C}-\mathrm{H}$ stretching modes are not affected; however, their relative intensities are a function of the extent of hydrolysis and condensation (not shown).

(18) (a) Sagiv, J. J. Am. Chem. Soc. 1980, 102, 92. (b) Gun, J.; Sagiv, J. J. Colloid Interface Sci. 1986, 112, 457. (c) Tillman, N.: Ulman, A.; Penner, T. L. Langmuir 1989, 5, 101. (d) Wasserman, S. R.; Tao, Y.T.; Whitesides, G. M. Langmuir 1989, 5, 1074.
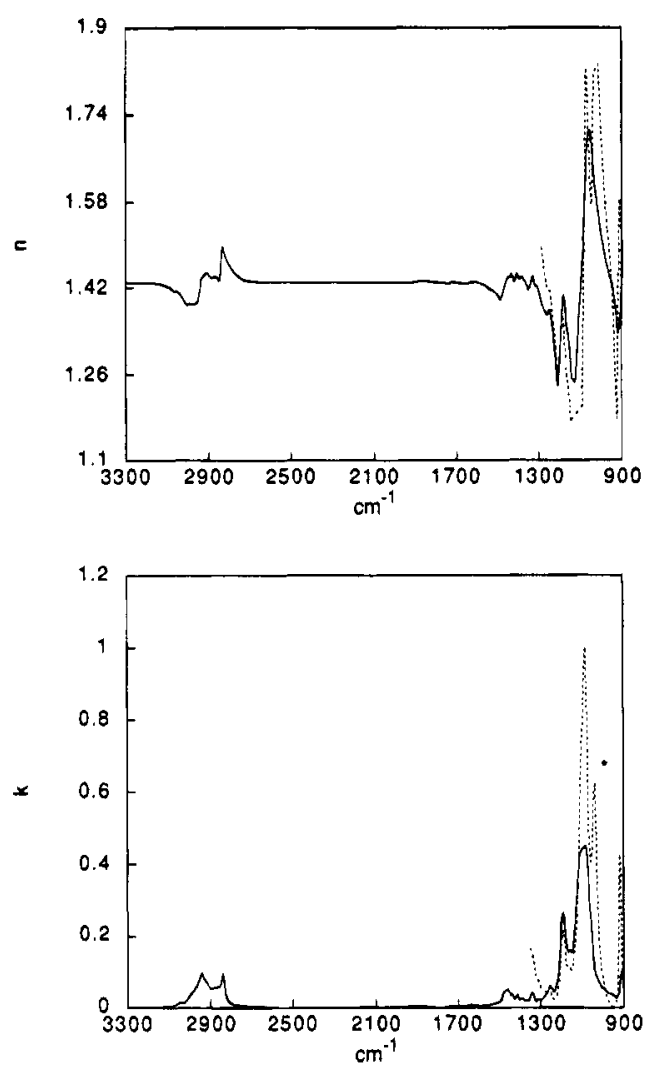

Figure 1. Isotropic optical response function of liquid GPS (solid line) and GPS/MeCN (dashed line): (top) n spectrum; (bottom) $\mathrm{k}$ spectrum. ${ }^{*} \mathrm{MeCN}$.

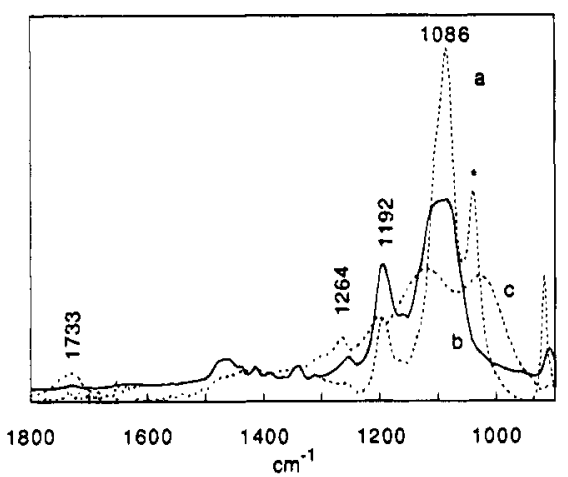

Figure 2. Normalized transmission IR spectra of GPS in various conditions: (a) GPS/acetonitrile mixture; (b) neat GPS (liquid); (c) cured GPS (solid). ${ }^{*} \mathrm{MeCN}$.

Table 1. Mode Assignments and Band Positions of Substituted Siloxanes ${ }^{a, b}$

\begin{tabular}{lll}
\hline $\mathrm{Si}-\mathrm{O}-\mathrm{Si}$ & $1130-1100$ & $\begin{array}{l}\text { several bands depending on structure } \\
\text { alkyl-substituted disiloxanes } \\
\text { siloxane polymer } \\
\text { (several maxima possible) } \\
1150-10000\end{array}$ \\
$\mathrm{Si}-\mathrm{O}-\mathrm{Me}$ & $1107-1100$ & $\begin{array}{l}\mathrm{Si}-\mathrm{O}-\mathrm{CH}_{3} \text {; asym } \mathrm{Si}-\mathrm{O}-\mathrm{C} \text { stretch } \\
\mathrm{CH}_{3} \text {, sym str (characteristic) }\end{array}$ \\
& 2840 & $\mathrm{CH}_{3}$, rock \\
$\mathrm{Si}-\mathrm{CH}_{2}$ & 1190 & $\mathrm{CH}_{2}$ def (wagging)
\end{tabular}

a See: (a) Smith, A. L. Spectrochim. Acta 1960, 16, 87. (b) Anderson, D. R. In: Analysis of Silicones; Smith, L. A., Ed. Wiley: New York, 1974; Chapter 10. (c) Bellamy, L. J. In The Infrared Spectra of Complex Molecules, 3rd ed.; Chapman and Hill: New York, $1975 .{ }^{b}$ The methylene $\mathrm{C}-\mathrm{H}$ modes adjacent to oxygen are weak.

To model the surface reactions of GPS, we heated freshly deposited films (several monolayers thick) of GPS on gold in the spectrometer. This allows us to observe the beginning of the hydrolysis reactions in situ. 
Table 2. Band Positions and Assignments for GPS Transmission Spectra ${ }^{a}$

\begin{tabular}{|c|c|}
\hline $\begin{array}{l}\text { freq } \\
\left(\mathrm{cm}^{-1}\right)\end{array}$ & assignment \\
\hline 3049 & $\mathrm{CH}_{2}$, str of epoxy group \\
\hline 2995 & $\mathrm{CH}_{2}$ propyl [2925/2850] \\
\hline 2942 & $\mathrm{CH}_{2}$ glycidyl (several overlapping bands) \\
\hline 2873 & {$\left[\mathrm{CH}_{3}[2945]\right.$} \\
\hline 2839 & $\mathrm{CH}_{3}$, sym str \\
\hline 1733 & $\mathrm{HC}=\mathrm{O}$, sym str \\
\hline 1465 & $\mathrm{CH}_{2}$, scissor \\
\hline 1260 & $\begin{array}{l}\mathrm{COC} \text {, sym str of epoxy groups } \\
\left.\quad \text { interference with } \mathrm{CH}_{2} \text { def in } \mathrm{SiCH}_{2}\right]\end{array}$ \\
\hline 1192 & $\mathrm{CH}_{3}$, rock \\
\hline 1100 & $\begin{array}{l}\mathrm{Si}-\mathrm{O}-\mathrm{C} \text {, asym str } \\
\quad \text { (interference with } \mathrm{C}-\mathrm{O}-\mathrm{C} \text { band }[1150-1070])\end{array}$ \\
\hline 910 & COC, asym str of epoxy ring \\
\hline 821 & $\mathrm{COC}$, epoxy ring $/ \mathrm{Si}-\mathrm{O}-\mathrm{C}$ sym str \\
\hline
\end{tabular}

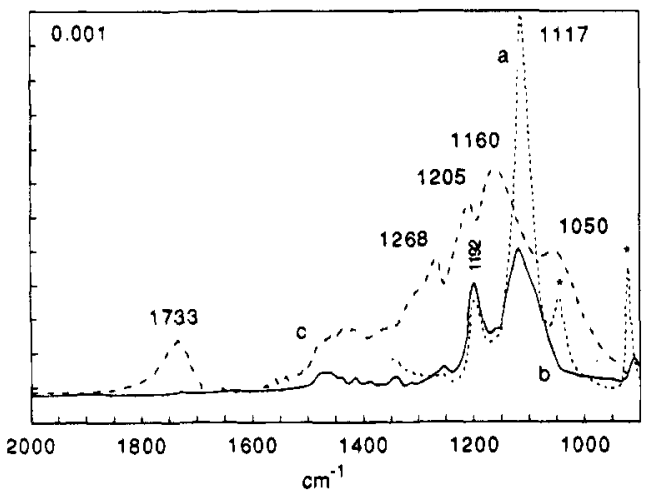

Figure 3. RA simulations of GPS films on gold based on the transmission spectra in Figure 2. Angle of incidence $84^{\circ}$, film thickness $15 \AA$. (a) GPS/acetonitrile mixture; (b) neat GPS (liquid); (c) cured GPS (solid). ${ }^{*} \mathrm{MeCN}$.

Figure 4 shows the RAIR spectra of the $\mathrm{C}-\mathrm{H}$ and $\mathrm{Si}-\mathrm{O}$ stretching region as a function of the hydrolysis and condensation reactions (radiative heating with $100 \mathrm{~W}$ light bulb $7 \mathrm{~mm}$ above sample; at $75^{\circ} \mathrm{C}$, total heating time $4 \mathrm{~h}$ ). The samples were prepared by applying a known amount of GPS dissolved in methanol to the wafer. We notice a decrease in the intensity during the heating process; probably some material desorbed. The $\mathrm{Si}-\mathrm{O}$ pattern of the first spectrum (top) is equivalent to the solution spectrum of GPS. The degree of condensation is low at this point. As the reactions proceed, we observe the disappearance of the $1196 \mathrm{~cm}^{-1}$ band, apparently due to loss of methoxy groups. At the end point, the spectrum shows one broad band with a maximum at $1125 \mathrm{~cm}^{-1}$. This band is at a lower energy compared to that of solution-polymerized GPS shown in Figure 3c. The difference could be related to the twodimensional nature of the surface-confined siloxane network. (For thick films of GPS we observe a pattern more similar to that shown in Figure 3 with a band at $1203 \mathrm{~cm}^{-1}$, a strong band at $1145 \mathrm{~cm}^{-1}$, and shoulders at 1070,1120 , and $1160 \mathrm{~cm}^{-1}$ ).

The band at $1733 \mathrm{~cm}^{-1}$ is of little intensity, indicating only a small amount of carbonyl formation. As the reaction progresses, the $\mathrm{C}-\mathrm{H}$ stretching region is characterized by the loss of the modes for the methoxy groups.

Vapor-Phase Adsorption of GPS. Films of molecular thickness are prepared by vapor adsorption of neat GPS at room temperature or at elevated tempera-
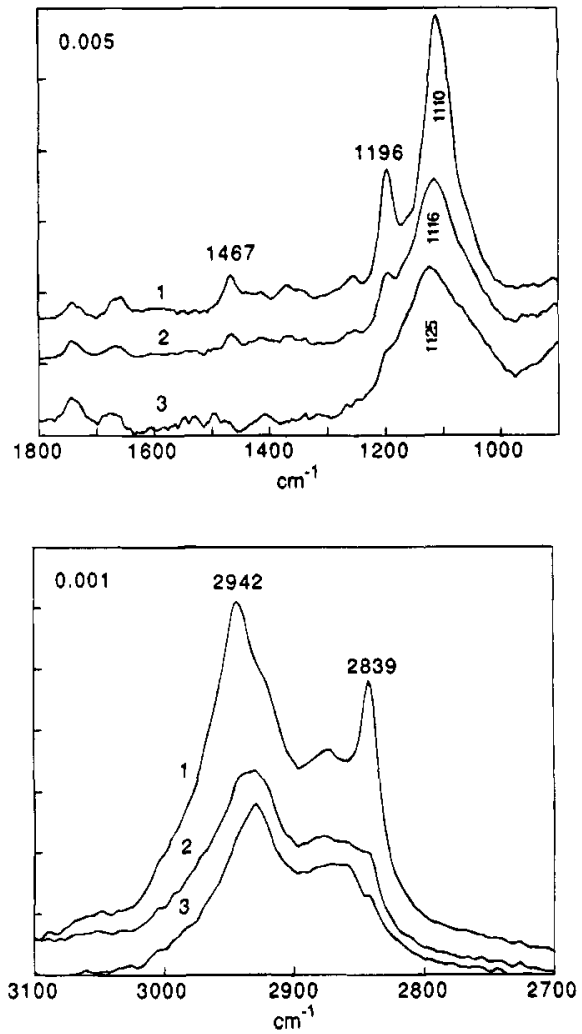

Figure 4. RA spectra of GPS adsorbed on gold as a function of hydrolysis and condensation reactions ( 1 , first spectrum; 3 , last spectrum after heating at $75^{\circ} \mathrm{C}$ for a total of $4 \mathrm{~h}$ ).

ture $\left(50{ }^{\circ} \mathrm{C}\right)$ to accelerate adsorption and improve adhesion. Preadsorbed water is indispensable for permanent attachment, as indicated by RA spectroscopy and QCM measurements. Evacuation of the sample at room temperature rapidly removes physisorbed GPS from the substrate. The remaining films have an average film thickness of $16 \pm 1 \AA$ (ellipsometry). An extended GPS molecule has a length of about $15 \AA$. A small imaginary part of the thickness $(0.8 \AA)$ indicates that the system is well-described with homogeneous planar layers.

Dynamic adsorption on a QCM from a nitrogen/GPS stream followed by evacuation results in a surface loading of $88 \mathrm{ng} / \mathrm{cm}^{2}(\Delta f 52 \mathrm{~Hz})$ or 3.0 molecules $/ \mathrm{nm}^{2}$ if we assume attachment of $=\mathrm{SiR}(\mathrm{OMe})$ moieties on the surface. This corresponds to $33 \AA^{2} /$ molecule and exceeds that of highly organized hydrocarbon films $\left(20 \AA^{2}\right)$. At approximately $25 \AA^{2} /$ molecule, a perpendicular orientation of the adsorbate is expected. ${ }^{19,20}$

Figure 5 shows the RA spectrum of vapor-adsorbed GPS and the RA simulation, based on liquid GPS. The bands for the methoxy groups at 1190 and $2844 \mathrm{~cm}^{-1}$ are weaker than in the simulation, indicating partial hydrolysis (or possibly orientation effects). The shape and position of the band at $1112 \mathrm{~cm}^{-1}$ are characteristic for polysiloxane formation with a low degree of condensation (compare to Figure 4). The bands at 826, 1265, and the shoulder at $3044 \mathrm{~cm}^{-1}$ are attributed to the epoxy groups. ${ }^{21}$

(19) Blum, F.; Meesiri, W.; Kang, H. J.; Gambodi, J. E. J. Adhes. Sci. Technol. 1991, 5, 479 .

(20) Naviroj reported a surface projection of 24 and $55 \AA^{2}$ for (methacryloxypropyl)trimethoxysilane (MPS), comparable in size to GPS, for a parallel and perpendicular orientation (Naviroj, S.; Culler, S. R.; Koenig, J. L.; Ishida H. J. Colloid Interface Sci. 1984, 97, 308). 

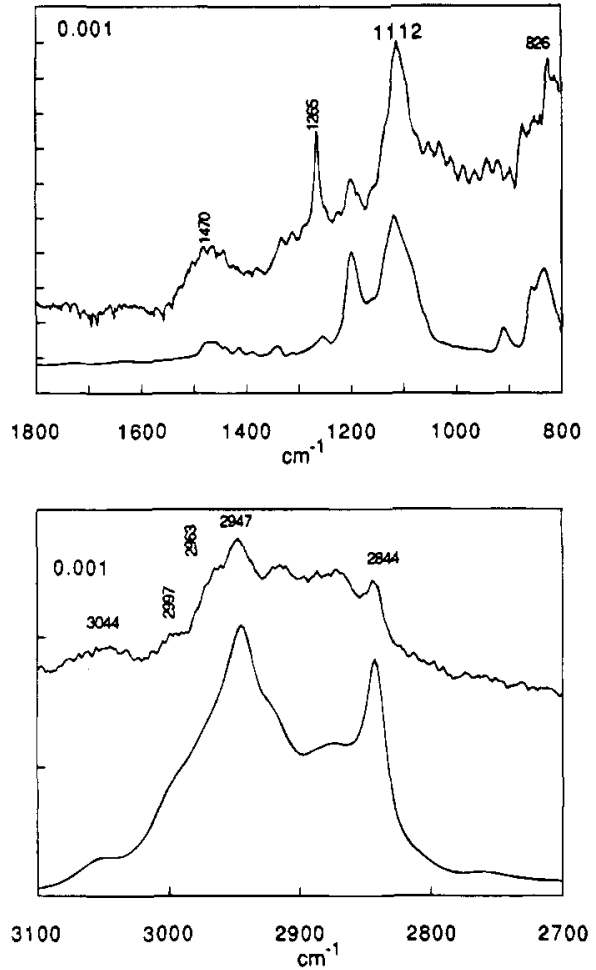

Figure 5. RA spectrum (top) and RA simulation (bottom) of GPS vapor adsorbed on gold ( $d, 14 \AA$; aoi, $84^{\circ}$ ).

The relative enhancement of the band at $1265 \mathrm{~cm}^{-1}$ in the RA spectrum in comparison with the RA simulation is probably a result of the particular orientation of the transition dipole moment with respect to the surface. The ether group as well as the methylene adjacent to silicon absorb both in this region. ${ }^{22}$ The enhancement is a significant departure from an isotropic IR signature which shows that the glycidoxypropyl groups are oriented. Films deposited via dipcoating from solution are typically thicker and show an isotropic spectrum (see Figure 4). Adsorption of GPS vapor under ambient conditions (humid air) results in multilayer formation; layers with thickness exceeding $100 \AA$ are readily achieved.

Immobilization of Poly(ethylenimine) (PEI). Regnier has described a very durable anion-exchange resin for chromatography based on PEI adsorbed on silica and cross-linked into stable layers by resins, alkyl bromides, or nitro alcohols. ${ }^{23}$ We extend this concept by binding PEI to gold substrates covered with an epoxy monolayer based on GPS. In addition, subsequent cross-linking of the immobilized PEI can produce a two-dimensional network. A suitable cross-linker is EPON, ${ }^{16}$ a commercial diepoxide with many applications.

PEI (mol wt 600) was applied from methanol solutions to the substrate modified with a GPS monolayer and heated in air at $78^{\circ} \mathrm{C}$ for $2 \mathrm{~h}$. The PEI layer is rather weak but cannot be washed off, indicating bonding with the underlying GPS film. PEI does not attach to blank

(21) The $\mathrm{C}-\mathrm{H}$ deformation mode of alkylsilanes interferes in this region. Assignment is thus somewhat ambiguous.

(22) The $\mathrm{Si}\left(\mathrm{CH}_{2}\right)$ deformation absorbs between 1200 and $1250 \mathrm{~cm}^{-1}$ and the $\mathrm{C}-\mathrm{O}-\mathrm{C}$ stretch of the eopxy ring absorbs at $1250 \mathrm{~cm}^{-1}$ (see: Nakanishi, K.; Solomon, P. H. In Infrared Absorption Spectroscopy, 2nd ed., Holden-Day, Inc.: Oakland, CA, 1977, p 31. Bellamy, L. J. In The Infrared Spectra of Complex Molecules, 3rd. ed.; Chapman and Hall: New York, 1975; p 377).

(23) Vanecek, G.; Regnier, F. E. Anal. Biochem. 1982, 121, 156.

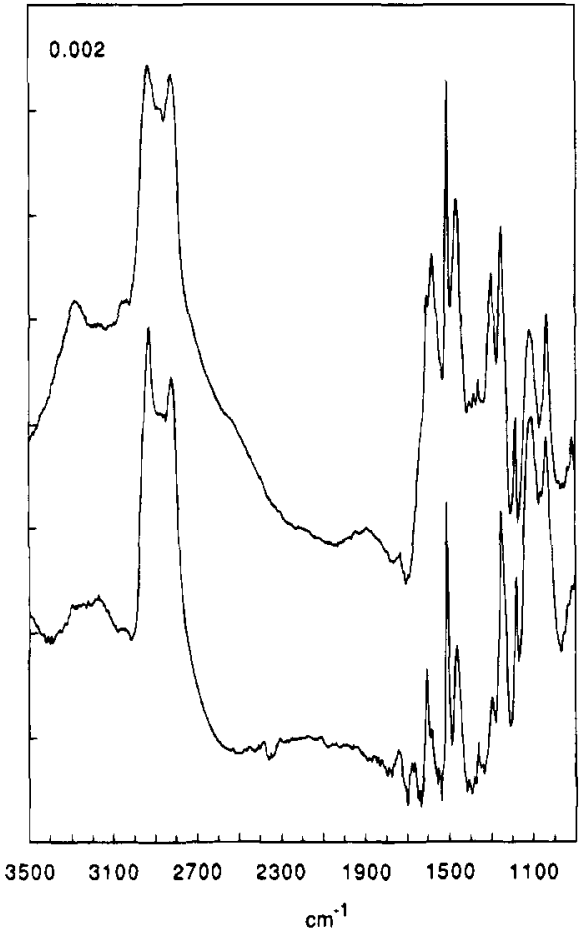

Figure 6. RA spectrum of PEIEPON before (top) and after heating (bottom) attached on gold. The spectrum of a PEI/ EPON film treated with $\mathrm{BF}_{3}$ at room temperature is similar to the latter heat treatment.

Table 3. Peak Positions and Assignments for PEI (Mol Wt 600, Transmission)

\begin{tabular}{|c|c|}
\hline freq $\left(\mathrm{cm}^{-1}\right)$ & assignment \\
\hline 3282 & NH, str (several bands) \\
\hline $\left.\begin{array}{l}2888 \\
2817\end{array}\right\}$ & $\mathrm{CH}$, str \\
\hline 1598 & $\mathrm{NH}, \operatorname{str}$ (free) (shoulder at $1610 \mathrm{~cm}^{-1}$ ) \\
\hline 1457 & $\mathrm{CH}_{2}$, scissor \\
\hline 1355 & $\mathrm{CH}_{2}$, wag, twist (broad band) \\
\hline 1294 & $\mathrm{C}-\mathrm{N}$ \\
\hline $\begin{array}{l}1122 \\
1050\end{array}$ & \\
\hline
\end{tabular}

gold wafers. To achieve cross-linking in the film, micromolar solutions of PEI and EPON were applied by dip-coating the GPS-modified gold surfaces.

To achieve even coatings, the substrates were dipcoated three times with a $1.4 \mu \mathrm{m}$ solution containing one part of PEI and one part of EPON. The resulting surface loading on a QCM is $1.8 \mu \mathrm{g} / \mathrm{cm}^{2}$ (measured in vacuum). The film thickness is $190 \pm 23 \AA$ (ellipsometry). The surface loading of a film of $190 \AA$ thickness is expected to be $1.9 \mu \mathrm{g} / \mathrm{cm}^{2}$. These results are in good agreement with respect to surface coverage and film thickness.

Subsequent exposure to vapors of $\mathrm{BF}_{3}$-etherate crosslinks PEI further to form a texture that is not removed from the surface by washing with water. Treatment with $\mathrm{BF}_{3}$-etherate vapors and rinsing with methanol changes the frequency response of the QCM by less than $2 \%$. Similar cross-linking reactions occur when heating the PEI/EPON film (see below).

Figure 6 shows the RA spectrum of a PEI/EPON film. Tables 3 and 4 summarize the band positions and assignments of transmission data for PEI and EPON. The IR signature is rich, and several group frequencies overlap. We notice changes in the relative intensities 
Table 4. Peak Positions and Assignments for EPON (Transmission)

\begin{tabular}{|c|c|}
\hline freq $\left(\mathrm{cm}^{-1}\right)$ & assignment \\
\hline 3050 & $\mathrm{CH}$, str phenyl, epoxy \\
\hline $\left.\begin{array}{l}2966 \\
2927 \\
2871\end{array}\right\}$ & $\mathrm{CH}$, str \\
\hline $\left.\begin{array}{l}1608 \\
1581 \\
1510\end{array}\right\}$ & $\mathrm{C}=\mathrm{C}$, str phenyl \\
\hline $\begin{array}{l}1247 \\
1184\end{array}$ & $\begin{array}{l}\text { COC, sym str epoxide, ether } \\
\text { COC, str (?) }\end{array}$ \\
\hline $\begin{array}{l}1035 \\
920 / 831\end{array}$ & $\begin{array}{l}\text { COC, sym str } \\
\text { epoxy }\end{array}$ \\
\hline
\end{tabular}

Table 5. Peak Positions and Assignments for Layers of PEI/EPON Reacted with HSiClMe,

\begin{tabular}{cl}
\hline freq $\left(\mathrm{cm}^{-1}\right)$ & \multicolumn{1}{c}{ assignment } \\
\hline 2964 & $\mathrm{CH}_{3}$, str, adjacent to $\mathrm{Si}$ \\
2217 & $\mathrm{SiH}$, str, adjacent to $\mathrm{O}$ \\
2134 & $\mathrm{SiH}$, str, adjacent to $\mathrm{N}$ \\
1263 & $\mathrm{CH}_{3}$, def, adjacent to $\mathrm{Si}$ \\
1108 & $\mathrm{Si}-\mathrm{O}$, str
\end{tabular}

of some peaks if the film was heated to $75^{\circ} \mathrm{C}$ inside the spectrometer (Figure 6). The bands at 3200,1600 , and $1250 \mathrm{~cm}^{-1}$ are affected; they are associated with the $\mathrm{N}-\mathrm{H}$ stretching and deformation modes and the $\mathrm{COC}$ stretch of the epoxide.

To obtain a semiquantitative measure of the chemical reactivity of the PEI/EPON films, they were exposed to vapors of $\mathrm{HSiClMe}_{2}$ at room temperature under nitrogen, then rinsed with $\mathrm{MeOH}$. Additional peaks at 1108, $1263,2134,2217$ and $2964 \mathrm{~cm}^{-1}$ are all due to the attached $\mathrm{HSiClMe}_{2}$ (Table 5). $\mathrm{HSiClMe}_{2}$ may react with the amino groups and with the alcohol groups present in the film. The bands at 2134 and $2217 \mathrm{~cm}^{-1}$ are assigned to the respective $-\mathrm{NSiH}$ and $-\mathrm{OSiH}$ vibrations. ${ }^{7}$ We measure an increase in the film thickness from $95 \AA$ for the PEI/EPON coating to $116 \AA$ after the reaction. A QCM coated with $1.6 \mu \mathrm{g} / \mathrm{cm}^{2}$ shows an additional mass of $0.15 \mu \mathrm{g} / \mathrm{cm}^{-2}$ after the reaction. As the accurate number of reactive sites within the film is unknown, it is difficult to say how many sites have reacted. The results demonstrate that the surface of the PEL/EPON films shows chemical reactivity.

Chemical Stability of PEI/EPON Films. The film integrity in aqueous solutions was investigated as a function of temperature and $\mathrm{pH}$ by cyclic voltammetry (CV). Octadecylmercaptan (ODM) and octadecyltrichlorosilane (OTS) monolayers on gold served as reference samples. These systems are particularly well suited for this purpose because they form insulating barriers to interfacial electron transfer, in particular ODM. ${ }^{24}$ Disruption of the film will result in an enhanced Faradaic response. The Faradaic response of the film-electrode interface can thus probe the structural integrity of the film as a function of the environmental conditions. ${ }^{25,26}$ Of course, this method is limited to systems that form insulating layers.

(24) (a) Porter, M. D.; Bright, T. B.; Allara, D. L.; Chidsey, C. E. D J. Am. Chem. Soc. 1987, 109, 3559. (b) Miller, C.; Cuendet, P.; Graetzel, M. J. Phys. Chem. 1991, 95, 877. (c) Finklea, H. O.; Robinson, L. R.; Blackburn, A.; Richter, B. Allara, D.; Bright, T. Langmuir 1986, 2, 239. (d) Weisshaar, D. E.; Walczak, M. M.; Porter, M. D. Langmuir 1993, 9, 323. (e) Finklea, H. O.; Ravenscroft, M. S.; Snider, D. A Langmuir 1993, 9, 223.
Temperature-dependent electrochemistry was performed in a standard three-electrode cell. The heating rate was approximately $1-2{ }^{\circ} \mathrm{C} / \mathrm{min}$; samples were kept at the top temperature $\left(100^{\circ} \mathrm{C}\right)$ for $1 \mathrm{~h}$. Electrodes were polished with alumina paste and cleaned in piranha prior to film formation. We chose $\mathrm{K}_{3} \mathrm{Fe}(\mathrm{CN})_{6}$ as the redox-active species, because it undergoes a reversible one-electron transfer at metal electrodes; the rate of electron transfer is independent of $\mathrm{pH}$ in the range $3-9 .{ }^{27}$

For octadecylmercaptan (ODM) films we did not observe Faradaic reduction current at neutral $\mathrm{pH}$ up to the limiting temperature of $100{ }^{\circ} \mathrm{C}$ (compared with the blank electrode; Figure 7A); the current is mostly capacitive. The $i-E$ response is independent of the scan direction. The data indicate that the reduction of $\mathrm{Fe}(\mathrm{CN})_{6}{ }^{3-}$ is inhibited. The ODM layer on gold thus maintains its structural integrity at neutral $\mathrm{pH}$ in the temperature range $25-100^{\circ} \mathrm{C}$. At basic $\mathrm{pH}$ we observed a steady increase of minor redox activity with increasing temperature. A scan of the sample cooled to room temperature now shows a Faradaic current (Figure 7B). This indicates that the film integrity has been slightly damaged during heating. At acidic $\mathrm{pH}$ we found rapid deterioration of the film above $45^{\circ} \mathrm{C}$. Above $90^{\circ} \mathrm{C}$ the $i-E$ curve approximates the response of the clean electrode.

Films of OTS on gold are oriented as their mercaptan counterpart but are not crystalline; for this reason, they do not block electron transfer as efficiently as the former. At basic $\mathrm{pH}$ the $i-E$ curve shows an increase in current as the temperature rises. The faradaic current is approximately 5 times greater than the ODM/ gold electrode at $25{ }^{\circ} \mathrm{C}$ after heating to $100{ }^{\circ} \mathrm{C}$ for $1 \mathrm{~h}$ (Figure 7C).

Single coatings of PEI/EPON immobilized on GPScoated gold electrodes show some electrochemical activity. Heating the electrochemical cell resulted in an increase of the Faradaic current. We conclude that a single coating gives an incomplete coverage; thus, the number of coatings was increased to three.

To promote cross-linking in the film, we treated the coating with vapors of $\mathrm{BF}_{3}$ at room temperature. Mixtures of 1 part PEI and 20 parts EPON were applied from $1.0 \mu \mathrm{m}$ solution in $\mathrm{MeOH}$ three times and exposed to vapors of $\mathrm{BF}_{3}$. The thickness of these coatings is approximately $150 \AA$, as determined on larger gold surfaces. The above coating technique leads to a dramatic improvement in hydrolytic stability of the PEI/ EPON films.

Electrodes were analyzed in the temperature range $25-100{ }^{\circ} \mathrm{C}$ at $\mathrm{pH} 6$ and 9. At room temperature, no measurable Faradaic current was observed at both $\mathrm{pH}$ values. Upon heating to $100^{\circ} \mathrm{C}$, only minute Faradaic responses were discernible (Figure 8A,B). Even at 60 ${ }^{\circ} \mathrm{C}$, the PEI film shows still capacitive behavior with current far less (about 20x) than that of the ODM film unheated at $25^{\circ} \mathrm{C}$ (compare Figures 7B and 8B). Under

(25) Chidsey, C. E. D. Science $1991,251,919$; Li, T. T. T.; Weaver, M. J. J. Am. Chem. Soc. 1984, $106,6107$.

(26) (a) Ikeda, T.; Schmehl, R.; Denisevich, P.; Willman, K.; Murray, R. W. J. Am. Chem. Soc. 1982, 104, 2683. (b) Amatore, C.; Saveant, J. M.; Tessier, D. J. Electroanal. Chem. 1983, 147, 39.

(27) Deakin, M. R.; Stutts, K. J.; Wightman, R. M. J. Electroanal. Chem. 1985, 182, 113 . 

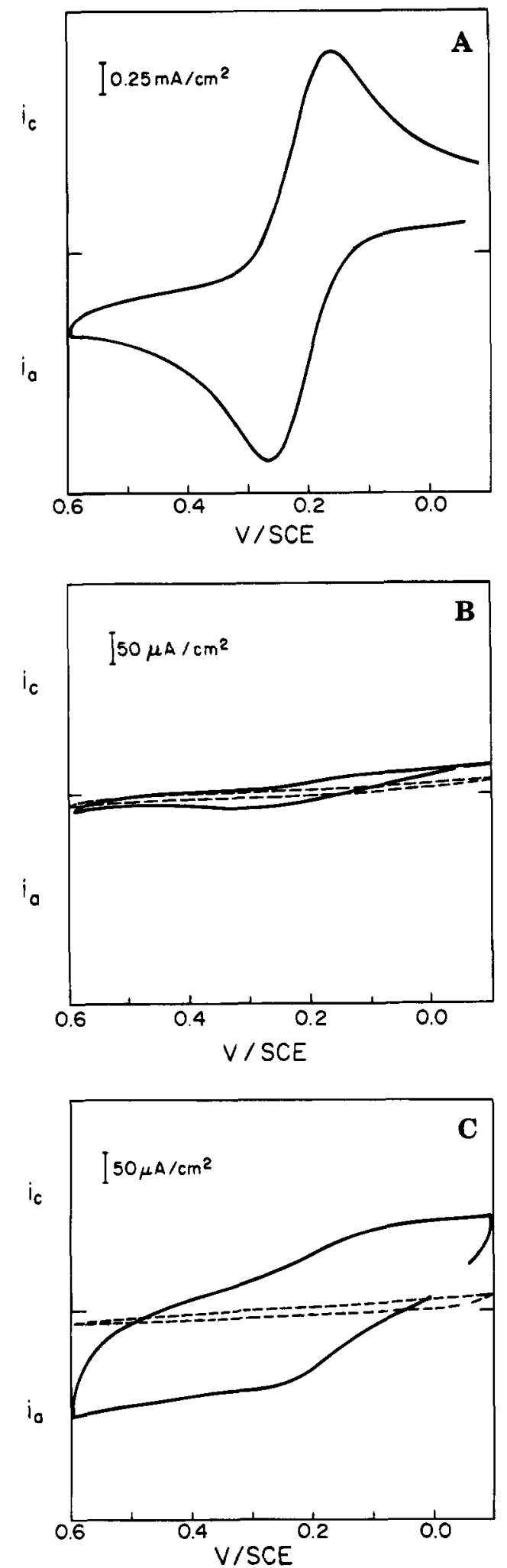

Figure 7. Cyclic voltammograms, taken at $25^{\circ} \mathrm{C}$ : (A) blank electrode, at $\mathrm{pH} 6$; (B) ODM, at $\mathrm{pH} 9.3$, (dashed line) before heating; (solid line) after heating at $100{ }^{\circ} \mathrm{C}$; (C) OTS, at pH 9.3, (dashed line) before heating, (solid line) after heating at $100{ }^{\circ} \mathrm{C}\left(1 \mathrm{mM} \mathrm{Fe}(\mathrm{CN})_{6}{ }^{3-}\right.$ in $1 \mathrm{M} \mathrm{KCl}$; sweep rate $\left.200 \mathrm{mV} / \mathrm{s}\right)$.

acidic conditions at $55{ }^{\circ} \mathrm{C}$, a discernible but small Faradaic response of $\mathrm{Fe}(\mathrm{CN})_{6}{ }^{3-}$ is observed (Figure $8 \mathrm{C}$ ), indicating some degree of swelling or hydrolysis.

In a comparative experiment, we boiled solid polymer material recovered from the coating mixture in $6 \mathrm{M} \mathrm{HCl}$ and $\mathrm{NaOH}$ for several hours under reflux. The FTIR
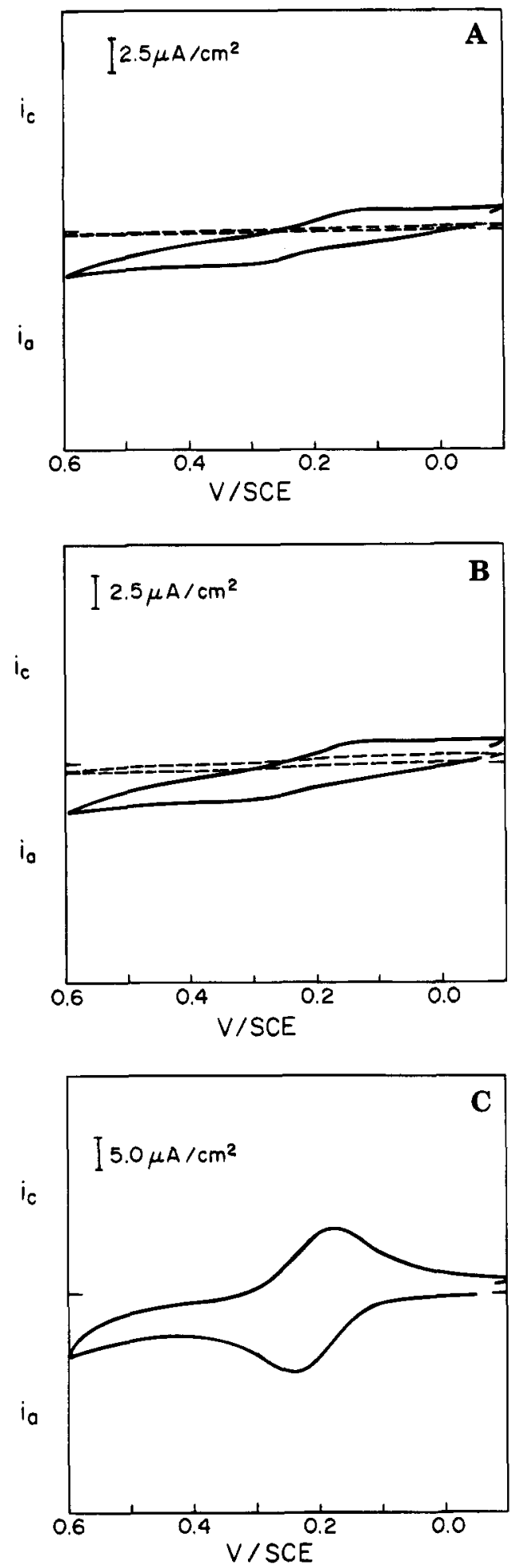

Figure 8. Electrochemical response of a PEI interface bonded with GPS on gold and cross-linked with EPON (taken at the temperatures indicated): (A) At pH 6.7 (dashed line) $60^{\circ} \mathrm{C}$, (solid line) $100^{\circ} \mathrm{C}$. (B) At $\mathrm{pH} 9.5$, (dashed line) $60^{\circ} \mathrm{C}$; (solid line) $100^{\circ} \mathrm{C}$. (C) At $\mathrm{pH} 3.9$ and $55^{\circ} \mathrm{C}\left(1 \mathrm{mM} \mathrm{Fe}(\mathrm{CN})_{6}{ }^{3-}\right.$ in $1 \mathrm{M}$ $\mathrm{KCl}$; sweep rate $200 \mathrm{mV} / \mathrm{s}$ ).

transmission spectra of the untreated and treated polymer samples are indistinguishable.

\section{Summary}

The adsorption of GPS vapor on gold results in films of monolayer coverage. RAIR spectroscopy shows that the films are partially cross-linked with a two-dimen- 
sional siloxane network. Ellipsometry and gravimetric analysis confirm an approximate monolayer formation. An approximately perpendicular orientation of the glycidoxypropyl group is proposed, based on surface coverage, ellipsometry and RA spectroscopy. Poly(ethyleneimine) (PEI) can be attached to the GPS films via reaction with the surface-bound epoxy groups. The chemical stability of the PEI films with thickness of 100-200 $\AA$ was examined with electrochemical methods. When cross-linked with EPON, the films are extremely durable in aqueous solutions with $\mathrm{pH}$ between 6 and 9 and temperatures up to $100^{\circ} \mathrm{C}$ for at least several hours. The neglible Faradaic response of these films is consistent with a continuous, dense coating.

A significant concentration of reactive surface sites (e.g., sec- $\mathrm{NH},-\mathrm{NH}_{2}$, and $-\mathrm{OH}$ ) are available as demonstrated in the reaction with a chlorosilane probe molecule. These films are promising candidates for barriers and functionalized surfaces.

Acknowledgment. The authors acknowledge financial support from the National Science Foundation (Division of Materials Research) (T.B.) and from the Army Research Office under Grant DAAL03-G-0144 (C.P.K.). 